\title{
Editorial
}

Martin Nitsche*

\section{Introduction to the Topical Issue "Phenomenology of Religious Experience III: Visuality, Imagination, and the Lifeworld"}

https://doi.org/10.1515/opth-2019-0029

This topical issue of Open Theology is the third volume guest-edited by the Society for Phenomenology of Religious Experience (SoPheRe). In this Society, we aim to describe, explicate, understand, and philosophically reflect upon religious experience by utilizing the phenomenological methods as they were developed by Husserl, Heidegger, and their followers. By religious experience we simply understand what is expressed as religious by those who go through it (we can speak about the lived religious experience). Inspired by Husserlian phenomenological reduction, we do not follow any theological definitions of "religious" or "divine". The expression of lived religious experience can be captured in texts, images, works of art, talks and discussions, architecture, etc. Our method is to reconnect these expressions to the structures of consciousness (or mind, if you wish) and detect a specific phenomenology of religious experience. We do not want to directly claim that consciousness contains specifically religious structures or processes; what we focus on, rather, are the distinctive ways that expressions of lived religious experience are connected to consciousness. Under the condition, we should add, that a consciousness is not interpreted in Cartesian sense, but (in accord with the phenomenological tradition) as characterized by embodiment and inter-subjectivity.

In this topical issue we concentrate mainly on visual expressions of lived religious experience. The theme includes a broad problematic ranging from imagination over visual perception to image representation. All religions and spiritual traditions distinctly articulate their relationship to images; some of them use imagination positively to enrich their teachings or practices, others, in contrast, strive to purify religious experience from every form of iconology. In any case, imagination and the relation to images belong among the most essential aspects of religious experience as such. And in the framework of our general aim to detect a specific phenomenology of religious experience by reconnecting expressions to the structures of consciousness, the topics we research in this issue encompass among others: image-consciousness, visual representations of religious experience (including visual works of art), religious imagination in theology, imaginative language of mysticism, images of divine beings, and visual mediation of religions.

The issue is opened by Michael Barber's thorough study "Objective, Intersubjective Mystical Relationships: Justification and Reality.” Following Schutz, Barber explores religious provinces of meaning and explains that "despite the lack of God's bodily presence" mystics experience God as a "Consociate". This main claim is further discussed by Barber with reference to William Alston's and Alvin Plantinga's conceptions of religious experience.

Carla Canullo follows up with an investigation of image-consciousness in the human experience of God. In her paper "God and Man as Unrepresentable Images" she claims that images that may occur within the framework of a religious experience cannot be understood as representations. Canullo argues, together with Jean-Luc Marion and his notion of icon, that the nature of these images of both human and divine beings must be theorized as the "unrepresentable".

*Corresponding author: Martin Nitsche, Czech Academy of Sciences, Prague, Czech Republic; E-mail: nitsche.martin@gmail.com 
Angela Ales Bello, in her paper entitled "Dual Anthropology as the Imago Dei in Edith Stein", shows that social norms can also become images of religious experience; she refers to Edith Stein's conception of a "dual anthropology" of male and female images of God (who created humans in his own image) and discusses it in relation to current gender studies.

The paper "The Way into Transcendental Philosophy from the Argument in Suhrawardi’'s Philosophy of Illumination" written by Olga Louchakova-Schwartz, addresses the phenomenal ground of visuality. Medieval Islamic philosopher Suhrawardi determines this ground to be visual light - a point usually missed in Suhrawardi scholarship. Suhrawardi argues that visual light and intuition (awareness) enjoy complete symmetry in their relationships to the objects they illumine. This serves as a foundation for the argument of the transcendental unity of knowledge. Suhrawardi's universe is based on the principle of self-evidentiality; consequently, by seeing or imagining, one taps into the very metaphysical "fabric" of the person and the world.

Martin Nitsche's paper concentrates on the transformative impact of religious conversions. He claims that the transformative impact of spiritual transformations consists not only in modifying life perspectives or values, but also (and more substantially) in changing the very structure of personal experience. The paper reflects on the possibilities the phenomenological method possesses to describe these changes, and mainly discusses the applicability of Husserl's analyses of the double constitution of the body.

In his paper "Transforming Representation: Jacques Derrida and the End of Christianity", Martin Koci analyses the ways in which current media transform representations of religious experience. Based on Derrida's logics of representation, he examines the relations between media and the proclaimed end of Christianity.

Maria Gołębiewska investigates the closeness between phenomenology and the work of Søren Kierkegaard. Her paper "Patheticness and Mundane Phenomenalisation of Transcendence according to Kierkegaard" addresses the issue's main theme, visuality and imagination, in the pure phenomenological way as the phenomenalisation of Transcendence. With reference to Kierkegaard, she describes pathetic religious responses to this phenomenalisation.

Petr Kouba analyzes sacrifice not only as a religious phenomenon, but also with respect to its moral and political dimensions. Commenting on the conceptions listed in the title of his paper "Phenomenology of Sacrifice in Patočka, Marion and Nancy", he achieves a very complex notion of sacrifice. Throughout the paper, he also discusses this notion in the context of the current misuse of sacrifice in terrorism.

In the final paper, "A Too-Future Eschatology? The Limits of the Phenomenology of Liturgy in JeanYves Lacoste", Jan Černý links the general topic of this issue to the philosophical reflections of liturgy. Whereas the main source of this paper, Jean-Yves Lacoste, rather undervalues the transformative power of liturgy, two other phenomenologists chosen by Černý, William Cavanaugh and Robert Kalivoda, represent the opposite approach.

Most of the papers in this issue were presented at the First Biennial Congress of the Society for the Phenomenology of Religious Experience, "Image, Phenomenon, and Imagination in the Phenomenology of Religious Experience”, which took place in Prague on November 2-4, 2018, at the Czech Academy of Sciences (hosted and generously supported by the Institute of Philosophy).

The editors of this issue would like to thank the Managing Editor of Open Theology, Katarzyna Tempczyk, for her insightful and very effective and productive approach to shaping all topical issues of SoPheRe. Our collaboration goes back to the very beginning of the Society in 2016, and Katarzyna's high professionalism, erudition, and open mind are indispensable in the creation of this collection. Editors work behind the scenes, but their background presence, akin to the background of consciousness itself, brings about the existence of research reports and literary works. Hence, we want to also thank our English language editor, Michael Fitzgerald, who knows and loves phenomenology and can handle difficult translations of specialized phenomenological narratives. Finally, as the author of this introduction I want to thank my co-editor, Olga Louchakova-Schwartz, for the excellent and effective cooperation (not only on this topical issue). 